\title{
Dialogical and Mediatory Potential of an Integral Ecology
}

\author{
Stanisław Jaromi \\ St. Francis of Assisi Environmental Movement (REFA) \\ Żółkiewskiego 14, 31-539 Krakow, Poland \\ sjaromi@franciszkanie.pl• ORCID 0000-0003-0719-6184
}

\section{Summary}

The encyclical Laudato si' is a Catholic document synthesizing the reflection on the main issues related to ecology as well as to nature and climate protection. It provides a new perspective for ecological activity in the light of integral ecology principles. In many countries, this encyclical has become a point of reference for Catholics in the context of the ecological crisis, especially by the fact of its highlighting the religious and spiritual perspective and giving concrete examples of both ecological and Christian lifestyles. Chapter 5 of the encyclical outlines, moreover, the concept of dialogue that brings hope for abandoning the spiral of self-destruction in which humanity is now sinking. The concept of communicative humanism and its mechanisms i.e. actions restoring values and creating a community have been proposed to establish the platform for this dialogue. The program is based on personalism and Christian hermeneutics, and its goal is a Church interested in the world and its problems, a one which on a par with others wants to say STOP to the destruction of the earth and its irresponsible exploitation.

\section{Keywords}

encyclical Laudato si', integral ecology, religion and ecology, dialogue

\section{Introduction}

The present times are challenging for the Church, but also for dialogue. The millenary optimism that accompanied us at the turn of the century was effectively undermined by subsequent conflicts, wars, persecution and terrorist acts. Thus, the question arises how this situation translates onto the relationship between science and faith, science and religion, and especially, onto the meeting point between ecology and Christianity?

A few years ago, I presented such a question to my students while conducting a series of lectures on this subject in Krakow within the Copernicus Centre project. During the first class we studied, among others, four models of relationships: conflict, independence, dialogue and integration. We found it quite easy to point out practical examples illustrating each of these relationships. However, it appears that there is yet another possible relationship, namely, that of indifference. It is a type of indifference characterized by a lack of interest in what others think, say, study, in the way they perceive, analyse, or interpret us... Indifference of scientists to the world of religion, theology, spirituality... but also indifference of theologians, the clergy or religious 
leaders to new scientific achievements, even when they regard problems concerning all of us. There are probably many reasons behind this situation, lack of an agora, i.e. a meeting space where we could exchange views, the rapidly changing trends, stratification of professional languages and failure to undertake the effort to gain a more thorough insight into the problems of related specialties.

\section{Franciscan message of Pope Francis}

On Friday morning, July 6, 2018, Pope Francis announced that he was looking for candidates for a special mission. Alluding to the call received by St. Francis of Assisi in the church of San Damiano, "Go and repair my house, which, as you can see, is falling into ruins", the Pope postulated that today the world needs those who will be able to realize that our planet is our "common home" and that it also is in ruins. Those chosen candidates must have ears sensitive enough to hear "the growing desperate cry of the earth and the cry of the poor who await our help and sense of responsibility." They must, moreover, accept as their own the papal project of integral ecology and, consequently, strive to rebuild harmony in relations with God, other people and nature, caring for their own spiritual ecosystem, radiating hope and constantly carrying out the ecological conversion. The Pope made the answer easier for the candidates for this extremely difficult mission by talking about the scientific data on the condition and crises of the world. We know that, as humanity, we possess the necessary knowledge and means to change the situation, but what the great of this world seem to lack is the will. Pope Francis mobilized the addressees of his speech, indicating the danger that we leave behind only "rubble, deserts and refuse" (Francis 2018).

I personally listened to these words during a special audience on the third anniversary of the encyclical Laudato si' when Pope Francis received nearly 300 Christian ecological activists from around the world, including representatives of the St. Francis of Assisi Environmental Movement, REFA, and blessed our projects. REFA was among the 12 Catholic ecological initiatives from around the world, which throughout the conference presented their activity and implemented projects, including the "School of Integral Ecology Leaders". At that time, the Pope asked for mutual prayer, whishing that the World Day of Prayer for the Care of Creation (Web-01) might be popularised.

REFA responded positively to Pope Francis' appeal to carry out this difficult task in our country by participating in numerous meetings and debates, visiting places of conflict, meeting everyone willing to meet... The papal eco-encyclical provides us with powerful tools. I have already recurrently spoken and written about its message (Poznański, Jaromi 2016; Jaromi 2016a; Jaromi 2016b; Hryniewicz, et al. 2016), but I would like to remind that the encyclical Laudato si' is a Catholic document synthesizing reflection on the main issues of ecology, nature conservation and climate protection, and also presenting a new perspective of ecological activity in the light of the principles of integral ecology (Sadowski et al. 2016). In many countries, the encyclical Laudato si' has provided an impulse for Catholics to open themselves to the care for the environment. Especially, since it addresses environmental issues using a different language than that of politicians, experts or activists. It provides a religious and spiritual perspective, showing concrete examples of both ecological and Christian lifestyles.

This encyclical, in Chapter 5, outlines the main ways of dialogue, which, as the Pope writes, will help us break free from the spiral of self-destruction in which we are sinking. The leitmotif in this document is presented by Francis on p. 160, when he asks: "What kind of world do we want to leave to those who come after us, to children who are now growing up?" and adds "Unless we struggle with these 
deeper issues, I do not believe that our concern for ecology will produce significant results. But, if we put them boldly, it leads us to further questions: Why are we going through this world? Why were we born? What do we work and fight for? Why does this land need us?" The Pope concludes with a comment: "It is no longer enough, then, simply to state that we should be concerned for future generations. We need to see that what is at stake is our own dignity. Leaving an inhabitable planet to future generations is, first and foremost, up to us. The issue is one which dramatically affects us, for it has to do with the ultimate meaning of our earthly sojourn" (Francis 2015: No. 160) and goes to various guidelines and proposals for actions contained in the chapter.

Let us recall here the main theses and titles of subsections: Dialogue on the environment in the international community (Francis 2015: No. 164-175), Dialogue for new national and local policies (Francis 2015: No. 176-181), Dialogue and transparency in decisionmaking (Francis 2015: No. 182-188), Politics and economy for human fulfilment (Francis 2015: No. 189-198), Religions in dialogue with science (Francis 2015: No. 199-201).

Dialogue, dialogue, dialogue - the most underrated and overlooked idea of Laudato $s i$. How to bring it to our ecological debate? It seems that in Poland there are currently three main areas of contention issuing from differing perceptions of ecological and social issues and leading to increasing tension, namely, 1) protection of biodiversity and our natural resources (including natural forests and rivers); 2) climate protection and debate about the shape of economic development, including energy production; 3 ) agricultural model and the related issues of landscape, soil erosion or healthy food. Each of these topics is viewed from different positions, from subjective assessments of local issues to such important topics as energy and food sovereignty as well as ecological security. I do not mention here the topic of air quality and the fight against smog, because it is widely considered important and there is a debate on ways to counteract this ecological threat.

Approaching the debate from the perspective of integral ecology, I would like to highlight the importance of the voice of Catholics, who constitute $87 \%$ of the country's population, in the decision-making processes regarding nature, environment and climate protection in Poland. According to research, $57 \%$ of Poles trust the Catholic Church, and $37 \%$ systematically and actively participate in the life of the Church (Sadłon 2019). However, there are many difficulties in the pro-ecological involvement of Polish Catholics issuing from, among others, lack of accessible knowledge, identification of ecology with ideology or failure to recognize the impact of global processes on life. It should also be noted that REFA's 35-years' ecological commitment dating back to 1984, has been focused on overcoming those barriers by popularizing the teaching of the Church, including the postulates of the encyclical Laudato si', in the context of human accountability for the world and its contemporary challenges.

When presenting the issue of dialogue, in addition to recalling the principles of rational discussion, it is indispensable to remember about the "legitimate diversity", since diversity is valuable both in the natural and social environment. Monoculture and unification are its direct opposite, which seems to be sometimes overlooked by environmentalists and politicians. For Christian ecologists, it is crucial to bear witness to God's love for all people by defending the dignity of the human person at every stage of his life, promoting peace and the common good, and striving to jointly build a just and humane society in which no one feels excluded or marginalized. What is also valuable, is the conviction that the only means to achieve peace are not weapons, the army, police or special services, but dialogue, forgiveness and reconciliation. Promoting a creative and modest lifestyle free of greed but based on greater generosity to protect the world of God and all its 
inhabitants is very helpful for overcoming distrust and created barriers.

At the beginning of March 2019, a conference was held in the Vatican on the goals of sustainable development and religious responsibility for the world perceived as our Common Home. The conference was also aimed at seeking methods of dialogue that would optimally respond to these challenges. The discussion often referred to both the encyclical Laudato si' and the Abu Dhabi declaration. While the encyclical is already quite well known, the declaration has not yet been widely popularized. It is a document that was signed in Abu Dhabi on 4.02.2019 by Pope Francis and the Grand Imam of Al-Azharr Ahmad Al-Tayyeb during the Pope's visit to Saudi Arabia. The starting point of the declaration is the conviction that believers should see in other person a brother or sister who need to be supported and loved. Then, it emphasizes the faith in God, who created the universe, all creation and people (who are equal due to $\mathrm{His}$ mercy). In addition, the declaration calls for the expression of human brotherhood by protecting the creation and the entire universe and supporting all people, especially those most impoverished and needy (Franciszek, Ahmad Al-Tayyeb 2019).

Such a point of departure allows one to provide answers to contemporary challenges and undertake efforts to spread the culture of mutual respect, being aware of God's great grace that makes all people brothers and sisters. This initiative has resulted in, among others, dialogue, leading to the minimizing many economic, social, political and environmental problems, involving especially believers who meet in the space of shared spiritual, human and social values (Francis 2019). There are also many indications that this dialogue avoids idle and unproductive discussions.

It is worth emphasizing that Pope Francis recurrently refers to Franciscan thought in the context of environmental issues. It seems that he discovers in it a source from which the Church can draw in its search for answers to the most difficult challenges of the present day. In addition, this thought helps to develop an appropriate language and way of thinking that we see in the presentation of integral ecology, the encyclical Laudato si', the Christian lifestyle and dialogue in the modern world (Jaromi 2018).

\section{Building the methodology of dialogue in the spirit of Laudato si'}

With the aim of building an ecological dialogue in the spirit of Laudato si', I would like to propose the concept of 'communicative humanism', which consists of two basic elements:

a. activities carried out on a vertical and horizontal plan and leading to the restoration of values;

b. activities carried out on a circular plane leading to the creation of the community.

The program is built on the base of personalism and Christian hermeneutics (Hryniewicz 1998). This approach indicates that dialogue can only make sense in a community, that it is based on the concept of the person expressing himself in dialogue (in relation to himself, another man, the world and God) and such a dialogue is a way to bring together the atomized and metaphysically sterilized societies. The encyclical Laudato si', besides defining all possible obstacles to dialogue, puts forward some solutions to repair the broken, poisoned and toxic bonds through the attitude of metanoia, a transformation initiated by "gratitude and gratuitousness, a recognition that the world is God's loving gift" (Francis 2015: No. 220).

Dialogue assumes the existence of the initiator and the recipient; since the Creator is the initiator, man is the recipient and he is endowed with both the ability to listen and to respond in a language created by God. Creation also participates in the dialogue, since the world is a Word - "universal communion" constituting a special form 
of existence of a mediatory and relational character. The Creator turns to the created persons and to the whole human race ontically and "phatically" through the world. The world thus constitutes a horizontal conversation (a dialogue held between people, between man and the earth or man and creation) as well as a vertical one (a dialogue between man and the Creator, the created and the uncreated, between the horizon of creation and salvation) (Krawiecka 2016: 219).

Pope Francis provides a hermeneutic interpretation of active Trinitarian relationality, in which the process of maturation takes place: "The divine Persons are subsistent relations, and the world, created according to the divine model, is a web of relationships... The human person grows more, matures more and is sanctified more to the extent that he or she enters into relationships, going out from themselves to live in communion with God, with others and with all creatures." (Francis 2015: No. 240). He argues further that "Christian spirituality proposes an alternative understanding of the quality of life, and encourages a prophetic and contemplative lifestyle, one capable of deep enjoyment free of the obsession with consumption" (Francis 2015: No. 222).

The idea of communicative humanism in the light of the eco-encyclical is universal and it is a manifestation of integral ecology, writes Ewa Krawiecka. It can be successfully used wherever dialogue (I - you - it), management skills (self-management and management of other entrusted goods) are necessary, development support, conscious participation in culture, ecological approach as the art of "a good and satisfying life" (Krawiecka 2016: 221).

When we speak for example about "human resource management", it means, in the understanding of integral ecology, personalistic human dialogue with the surrounding, the environment and other person, activities in the company, organization, group, family, society striving for the "community of people". In such a case, management is aimed at the comprehensive development of the human person (mental, ethical, intellectual, cultural, community, physical, etc.) and the pragmatism of action (of leaders, managers, entrepreneurs, teachers, culture animators, parents, social activists, etc.) means the courage to take responsibility for the people entrusted to them and ensuring that all relations are "ecological", i.e. devoid of the attitude to person as a resource, thing and far from disturbing the dialogue by various manifestations of aggression.

The task of communicative humanism, understood as a manifestation of integral ecology, is to re-humanize the language describing creation and the Creator. Because the language of aggression, manipulation, depersonalization is a sign of the actions of the enemy of the Word, and ecological transformation begins with the transformation of language as the basic tool allowing us to understand the world. Communicative humanism proposes one of the ways leading to ecological transformation and spirituality and calls for social, environmental, cultural, ecumenical and economic dialogue. It seems to be aimed at re-humanizing the key threats to the contemporary ecosystem by:

a. building integral ecology as ethical relations: I - you - the world;

b. care for the environment in a spirit of harmony and respect expressed in human dialogue with the Creation and the Creator;

c. personalistic integration of cultural, educational and economic activities in the process of sustainable and equitable development for the common good;

d. shaping the responsibility of various spheres of human activity in building a community based on interpersonal solidarity;

e. supporting a modern model of education propagating integral ecology;

f. integrating pro-ecological and personalistic attitudes as regards the sphere of secular and religious consciousness 
in the spirit of ecumenism, interreligious, multi-world and intergenerational dialogue (Krawiecka 2016: 223). There are many indications that these postulates answer the papal call to broaden the goals of ecological education. "Whereas in the beginning it was mainly centred on scientific information, consciousness-raising and the prevention of environmental risks, it tends now to include a critique of the "myths" of a modernity grounded in a utilitarian mindset (individualism, unlimited progress, competition, consumerism, the unregulated market). It seeks also to restore the various levels of ecological equilibrium, establishing harmony within ourselves, with others, with nature and other living creatures, and with God. Environmental education should facilitate making the leap towards the transcendent which gives ecological ethics its deepest meaning." (Francis 2015: No. 210)

\section{Conclusion}

A fine summary of this study may be provided by the words of Cardinal Maurice Piat from Mauritius, who at a conference on the goals of sustainable development and religious responsibility for the world organized in March 2019 in the Vatican, stated that the Church, following Jesus, should look for the lost ones and venture to the peripheries, not being afraid to immerse in the world's poverty and misery to proclaim the Good News there; the Church should constantly seek a balance between prayer and work, liturgy and diaconal work, between service to God and service to people and the world; the Church should be deeply convinced that it has something very important to offer to the world, namely, faith, hope, love and the whole message of the Gospel.

The Church which adopts integral ecology as its point of reference, will be interested in the world and its problems, and together with others it will firmly say STOP to the destruction of the earth as well as to the irresponsible exploitation of its resources; it will never consent to people's becoming waste in global processes, it will oppose to adopting such an attitude to children with defects or suffering from diseases, or to animals from mass breeding; such a Church will listen to the voice of science on climate issues and will not be indifferent to the numerous reports showing the relationship between the climate change and the world poverty, disease, food and energy production or the lifestyle.

The Church that Pope Francis portrays in the Laudato si' encyclical is not afraid to undertake cooperation with professionals and it approaches diverging views with respect. It perceives the United Nations, development and non-governmental organizations as important partners, recognizing dialogue as an essential method of activity and expanding the spaces of dialogue and activity to new areas. The Church, led by Pope Francis, understands that we share our planet with followers of other religions, other ethics and lifestyles, with those who are richer and those who are poorer than us; that there are more and more of us, and that the earth is becoming increasingly crowded, and although we are able to solve many problems together, there are still many challenges that need to worked on in the atmosphere of cooperation and by peaceful means. Such a Church chooses to implement the project initiated 800 years ago by St. Francis of Assisi, in which God is the Father of all people and all creation and in which we are brothers and sisters.

In 2019, a synod will take place related to the Amazon, an extraordinary region of the world that is huge, beautiful, delightful in its biodiversity, but at the same time is it being destroyed at an alarming rate. It seems, however, that the concept of dialogue promoted by Pope Francis indicates that it is insufficient to speak of this region unique in terms of nature as "the lungs of the world", "the natural heritage of humanity" or huge tropical forests. It is also necessary to notice the perspective of the local Amazonian reality (Jaromi, Olszewski 2010: 52-63). 
The Amazon is a world's sanctuary where nature still functions according to the original will of God the Creator. This is the perspective proposed by the synod on the way we should perceive the Amazon. It also seems to point the way for Polish Catholics to discover in the natural heritage of their homeland the sanctuaries of creation still inhabited by unique species: wolf, bear, bison, lynx, beaver, deer, elk and so many other inhabitants of our common home God's beautiful home.

\section{Bibliography}

Francis, 2019, Address of His Holiness Pope Francis to Participants at the Conference on "Religions and the Sustainable Development Goals (SDGS): Listening to the Cry of the Earth and of the Poor" (Vatican, 8.03.2019), <http://w2.vatican.va/ content/francesco/en/speeches/2019/march/ documents/papa-francesco_20190308_religionisvilupposostenibile.html $>$, accessed: 17.06.2019.

Francis, 2015, Encyclical letter Laudato si', (Rome, 24.05.2015) <w2.vatican.va/content/francesco/en/ encyclicals/documents/papa-francesco_20150524 enciclica-laudato-si.html>, accessed: 17.06.2019.

Franciszek, 2018, Przemówienie do uczestników konferencji z okazji trzeciej rocznicy encykliki «Laudato si'» (Speech addressed to conference participants on the third anniversary of the encyclical "Laudato si'» (Vatican, 6.07.2018) - <http://w2.vatican.va/content/ francesco/pl/speeches/2018/july/documents/papafrancesco_20180706_terzoanniversario-laudatosi. html>, accessed: 17.06.2019.

Franciszek, Ahmad Al-Tayyeb, 2019, Dokument o ludzkim braterstwie. Dla pokoju światowego $i$ wspótistnienia (Document on Human Fraternity for World Peace and Living Together) (Abu Zabi, 4.02. 2019), <http://w2.vatican.va/content/ francesco/pl/travels/2019/outside/documents/ papa-francesco_20190204_documentofratellanza-umana.html>, accessed: 17.06.2019.

Hryniewicz W., 1998, Hermeneutyka $w$ dialogu: szkice teologiczno-ekumeniczne (Hermeneutics in dialogue: theological and ecumenical sketches), vol. 2, Wydawnictwo św. Krzyża.

Hryniewicz W., Jaromi S., Weiner J., 2016, Ekologia (Ecology), Wydawnictwo Znak, Krakow.
Jaromi S., 2016a, Nadzieje Jana Pawła II zwiazane zochrona stworzenia (Hopes of John Paul II Related to the Protection of Creation), in: Jaromi S., HennelBrzozowska A. (ed.), "Losy nadziei świętego Jana Pawła II”, Wyd. Scriptum, Krakow, 131-142.

Jaromi S., 2016b, Franciszkańskie przestanie Laudato si'(The Franciscan Message of Laudato si'), Polonia Sacra, vol. 20, no. 3(44), 67-80.

Jaromi S., 2018, Idea franciszkańska. Wielkie problemy wspótczesności i nasze mate odpowiedzi (Franciscan Idea. Big Problems of the Present Day and Our Little Answers), Bratni Zew, Krakow.

Jaromi S., Olszewski M., 2010, Eco-booko Eko-Bogu (Eco-book aboutEco-God), Wydawnictwo Salwator, Krakow.

Krawiecka E., 2016, "Nawrócenie ekologiczne w stronę dialogu i humanizmu komunikacyjnego" (Church and Science in the Face of Ecological Challenges. Sources, Inspirations and Contexts of the Encyclical Laudato si'), in: Poznański J, Jaromi S. (ed.), Kościół i nauka w obliczu ekologicznych wyzwań. Źródła, inspiracje i konteksty encykliki Laudato si'”, Akademia Ignatianum w Krakowie, Wyd. WAM, Krakow.

Poznański J. Jaromi S. (ed.), 2016, Kościót i nauka w obliczu ekologicznych wyzwań. Źródta, inspiracje $i$ konteksty encykliki Laudato si' (Church and Science in the Face of Ecological Challenges. Sources, Inspirations and Contexts of the Encyclical Laudato si'), Wyd. WAM, Krakow.

Sadłoń W. (ed.), Annuarium Statisticum Ecclesiae in Polonia ad 2019, 2019, Instytut Statystyki Kościoła Katolickiego SAC im. Witolda Zdaniewicza, Warsaw, available online: <http://iskk.pl/images/ stories/Instytut/dokumenty/Annuarium Statisticum_2019.pdf>, accessed: 17.06.2019.

Sadowski R.F., Bołoz W., Jaromi S., Łepko Z., Papuziński a., Karaczun Z., 2016, Ekofilozoficzne przeslanie encykliki Laudato si'(Ecophilosophical Message of the Encyclical Laudato si'), Studia Ecologiae et Bioethicae, vol. 14, no. 4, 109-128.

(Web-01) REFA w Watykanie, <https://www. swietostworzenia.pl/2-aktualne/780-refa-wwatykanie>, accessed: 17.06.2019. 


\section{Dialogiczny i mediacyjny potencjał ekologii integralnej}

\section{Streszczenie}

Encyklika Laudato si' to katolicki dokument, która syntetyzuje refleksję nad głównymi tematami ekologii, ochrony przyrody i ochrony klimatu, prezentuje nową perspektywę dla aktywności ekologicznej w świetle zasad ekologii integralnej. W wielu krajach encyklika ta stała się punktem odniesienia dla katolików w kontekście kryzysu ekologicznego. Zwłaszcza, że daje prezentuje ona perspektywę religijną i duchową, pokazuje konkretne przykłady stylu życia jednocześnie ekologicznego i chrześcijańskiego. W rozdz. 5 kreśli też koncepcję dialogu, który daje nadzieję na porzucenie spirali autodestrukcji, w jakiej pogrąża się ludzkość. Dla budowy tego dialogu proponowana jest koncepcja humanizmu komunikacyjnego i jego mechanizmy, czyli działania restytuujące wartości i kreujące wspólnotę. Fundamentem programu jest personalizm i hermeneutyka chrześcijańska, a jego celem Kościół zainteresowany światem i jego problemami, który chce razem z innymi powiedzieć STOP niszczeniu Ziemi i jej nieodpowiedzialnej eksploatacji.

\section{Slowa kluczowe}

encyklika Laudato si', ekologia integralna, religia i ekologia, dialog

\section{Nota 0 autorze}

0. Stanišaw Jaromı OFM Conv. - doktor filozofii, wieloletni delegat franciszkanów ds. sprawiedliwości, pokoju i ochrony stworzenia, przewodniczący Ruchu Ekologicznego św. Franciszka z Asyżu (REFA) i szef portalu www.swietostworzenia.pl. Od ponad 30 lat aktywnie angażuje się na rzecz rozwoju chrześcijańskiej ekologii.

\section{Author's Note}

Fr. Stanistaw JaRomi OFM Conv. - Doctor of Philosophy, long-time Franciscan delegate for justice, peace and protection of creation, chairman of St. Francis of Assisi Environmental Movement (REFA) and head of the website www.swietostworzenie.pl. Over the last 30 years, he has been actively involved in the development of Christian ecology. 